\title{
THE EFFECT OF USING DIGITAL STORYTELLING ON STUDENTS' INTRINSIC MOTIVATION FOR LEARNING VOCABULARY
}

\author{
Tri Jampi Setiyorini \\ MI Az Zahra Cangkreplor, Purworejo \\ trijampi95@gmail.com
}

\begin{abstract}
ABSTRAK
Di sekolah dasar, kosakata adalah salah satu factor utama dalam pembelajaran bahasa. Namun, banyak siswa yang kurang termotivasi dalam belajar kosakata. Jadi, itu mempengaruhi penguasaan kosakata mereka. Penelitian ini bertujuan untuk menganalisis efek penggunaan digital storytelling terhadap motivasi intrinsik siswa dalam belajar kosakata dan mendeskripsikan keuntungan digital storytelling untuk meningkatkan motivasi intrinsik siswa dalam belajar kosakata. Jenis penelitian ini adalah studi kasus deskriptif. Subjek penelitian ini adalah 22 siswa SD Teladan Yogyakarta tahun pelajaran 2017/2018. Peneliti menggunakan angket tertutup dan wawancara. Studi ini menunjukkan bahwa ada perbedaan signifikan terhadap motivasi intrinsik siswa dalam belajar kosakata sebelum dan setelah menggunakan digital storytelling. Berdasarkan hasil angket, setelah menggunakan digital storytelling, motivasi intrinsik siswa dalam belajar kosakata lebih tinggi. Berdasarkan hasil wawancara, digital storytelling dapat meningkatkan motivasi instrinsik siswa dalam belajar kosakata karena medianya menarik dan situasi pembelajarannya menyenangkan.
\end{abstract}

Katakunci: kosakata, motivasi intrinsik, digital storytelling

\section{ABSTRACT}

In elementary school, vocabulary is the key factor in language learning. However, many students still have a lack of intrinsic motivation in learning vocabulary. Thus, it affects their vocabulary mastery. To overcome this problem, the researcher uses the digital storytelling to improve students' intrinsic motivation for learning vocabulary. This research aims at analyzing the effect of using digital storytelling on students' intrinsic motivation for learning vocabulary and describing the benefits of digital storytelling to improve students' intrinsic motivation for learning vocabulary. The type of this research is descriptive case study. The subjects of the study are 22 students of 2C of SD Teladan Yogyakarta in the academic year of 2017/2018. The researcher uses close-ended questionnaire and interview to collect the data. The study shows that there was significant difference before and after using digital storytelling towards students' intrinsic motivation in learning vocabulary. From the result of the questionnaires, after using digital storytelling, students' intrinsic motivation for learning vocabulary is higher. Based on the result of interviews, digital storytelling can improve students' intrinsic motivation for learning vocabulary due to interesting media and exciting learning situation.

Keywords: vocabulary, intrinsic motivation, digital storytelling

\section{INTRODUCTION}

In elementary school, vocabulary is important in language learning to make sentences to express thoughts and meanings (Bai, 2018). Vocabulary learning always emphasizes the meaning of new words in the books and in the classroom. Vocabulary competence is crucial for second-language learners because a restricted vocabulary impedes successful communication (Alqahtani, 2015). 
Learning vocabulary becomes the major challenge faced by students in their studies. As Wilkins puts it, very little can be transmitted without grammar; nothing can be transmitted without vocabulary (Alizadeh, 2016). Young learners' vocabulary development is an important aspect of their language development (Khorasgani \& Khanehgir, 2017).

Students of SD Teladan Yogyakarta are obliged to learn and master English as one of the international languages in the world. As one of the excellent schools in Yogyakarta, SD Teladan Yogyakarta demands students to master English because English is also one of the subjects which is always included in Olympics from district level to national level. Thus, English is not only included in compulsory subject, but also becomes the subject which is included in the competition. However, many students of SD Teladan Yogyakarta still have a lack of intrinsic motivation in learning vocabulary. They do not have great interest in learning vocabulary during the lesson, and it influences their grade. When they are learning vocabulary, they often focus on another activities such as: chatting with their friends, drawing, playing, or doing other things which are not related to learning. On the contrary, intrinsic motivation influences the success of L2 learning, especially for vocabulary mastery. If students have high intrinsic motivation in learning vocabulary, they will gain the optimal learning result.

Motivation is known to be an integral part of achieving every purpose which has a positive influence in any educational learning process. Woolfolk (1998) defines that motivation is an internal state which stimulates, guides, and maintains actions (Rehman et al., 2014). According to Hartnett (2016), motivation is necessary because it determines the continuity of a learner in a course, the level of interest, the quality of the work, and the level of achievement (Panagiotidis et al., 2018). A study conducted by Long, Ming, and Chen (2013) has proved that students need motivation to help them learn English. They should establish the right goal to learn English well. Meanwhile, as an organizer in teaching, teacher should pay more attention to communicative learning that can stimulate students to learn effectively.

There are two kinds of motivation; namely, intrinsic and extrinsic motivation. Intrinsic motivation is linked to the identity and sense of well-being of the individual, while extrinsic motivation comes from outside. Learners become intrinsically motivated when learning is done for satisfaction, and they become extrinsically motivated when learning is performed for 
rewards such as: gifts and grades $(\mathrm{Ng}$ \& Ng, 2015).

From the definitions, it can be concluded that motivation has a great influence in second language learning, especially for EFL learning because it rises, directs, and maintains people's behavior to keep learning a second language. It also determines the persistence of the learners in a course, the level of interest, the quality of work, and the level of achievement. Intrinsic motivation comes from inside the individual, while extrinsic motivation comes from outside the individual.

Intrinsic motivation appeared to be one of the most important concept in EFL classrooms (Al-Amri, 2019). A student who is intrinsically motivated learns because he or she wants to learn, and learning any activities is for satisfaction (Long et al., 2013). Students with intrinsic motivation will always learn although they face complicated problems, and even they learn from their mistakes and slips (Mahadi \& Jafari, 2012). A study conducted by laremenko (2017) has proved that online learning games can foster intrinsic motivation and help engage students in learning activities. The use of online games in English as a second language learning shows the direct relationship between a high energy level of competition and increases motivation.

Because intrinsic motivation is the important factor for learning, teachers should use different methods to enhance students' intrinsic motivation in learning, so students have a better understanding. The researcher believes that the use of digital storytelling (DST) can improve students' intrinsic motivation in learning vocabulary. Some preservice teachers have used digital storytelling as a tool for teaching. The results show that pre-service teachers perceived DST to be beneficial in the classroom as it has the potential to: (i) motivate and engage learners, (ii) promote voice/self-expression, and (iii) promote collaborative learning and acquisition of multiple skills (Tiba et al., 2013).

Digital storytelling is a way of telling and presenting stories through the use of digital media, graphics, sounds, and music (Robin, 2016). Digital stories consist of a mixture of graphics, text, recorded audio narration, video and music to present information on a specific topic through the use of technology (Alismail, 2015). Digital storytelling is beneficial to language learning as the language features (vocabulary, grammar, sentence structures and linguistic elements) are presented through digital stories (Amelia \& Abidin, 2018).

Digital storytelling is the act of telling a story with the use of digital technology, and integrating digital storytelling into English as a foreign 
language classroom has given a positive impact and notable increase in motivation and engagement for students (Al-Amri, 2019). Digital storytelling has become a modern art of oral storytelling because it enables anyone to create stories with moving images, music, and sound, combined with the author's creativity and innovation (Smeda et al., 2014). That media can be in the form of digital fable, digital folklore, or digital fairytales. It can be downloaded on the internet, and it can also be made by the teacher herself. When the teacher creates the digital storytelling, she can control the speed of the voice recording and set the numbers of sentences for each slide of the story, so students can follow the story well. In this research, the researcher designed the digital storytelling in bilingual; that is, in English and in Bahasa Indonesia, to make students have a better understanding about vocabularies and motivate them in learning vocabulary intrinsically.

Based on the background of the research above, the researcher intends to do the research entitled The Effect of Using Digital Storytelling on Students' Intrinsic Motivation in Learning Vocabulary. There are two statements of the problems in this research:

1. How is the effect of using digital storytelling on students' intrinsic motivation in learning vocabulary?
2. What are the benefits of digital storytelling to improve students' intrinsic motivation in learning vocabulary?

In line with the statements of the problems, there are two objectives of the research:

1. This research aims at analyzing the effect of using digital storytelling on students' intrinsic motivation in learning vocabulary.

2. This research aims at describing the benefits of digital storytelling to improve students' intrinsic motivation in learning vocabulary.

\section{METHOD}

To conduct the research, the researcher uses a descriptive case study. Descriptive case study aims only to present a detailed, contextualized picture of a particular phenomenon. It emphasizes to gain a deep understanding about the case (Heigham \& Croker, 2009). In this study, the researcher presents detailed information about the effect of using digital storytelling on students' intrinsic motivation in learning vocabulary and the benefits of using digital storytelling to improve students' intrinsic motivation in learning vocabulary of class 2C in SD Teladan Yogyakarta in the academic year of $2017 / 2018$, so this study belongs to a descriptive case study. The subjects of the study 
are 22 students of $2 \mathrm{C}$ of SD Teladan Yogyakarta in the academic year of $2017 / 2018$. The data was taken from 21 March 2018 to 18 April 2018. The data source of this research is documents. The documents are in the form of result of questionnaires and transcripts of interviews. To collect the data, the researcher uses close-ended questionnaire and oneon-one interview.

1. Technique of collecting data

a. Technique of collecting data 1 (questionnaire)

1) The researcher makes a sequence of questions.

2) The researcher asks for a permission to class $2 \mathrm{C}$ to take data.

3) The researcher gives the questionnaires.

4) The researcher explains how to fill in the questionnaire.

5) Students fill in the questionnaire.

6) Students submit their questionnaire.

b. Technique of collecting data 2 (interview)

1) The researcher makes a sequence of questions.

2) The researcher asks for permission to students of $2 \mathrm{C}$ to take data.

3) The researcher gives some questions to students of $2 \mathrm{C}$ and record the interview.
2. Technique of analyzing data

a. Technique of analyzing questionnaire

1) The researcher reads the result of questionnaires.

2) The researcher counts the result of questionnaires for 'Yes' and 'No'.

3) The researcher calculates each of the result of questionnaire and puts it into the table.

4) The researcher calculates the percentage for each of the result of the questionnaire and puts it into the table.

b. Technique of analyzing interview

1) The researcher listens the recording of the interview.

2) The researcher transcribes the recording of the interview.

3) The researcher interprets the result.

\section{RESULT AND DISCUSSION}

In this section, the researcher presents the result of the research. There are two parts in this section: the first is related to the first research question and the second is related to the second research question.

1. How is the effect of using digital storytelling on students' intrinsic motivation for learning vocabulary? 
Table 1. The Recapitulation of Students' Questionnaires

Students' Intrinsic Motivation in Learning Vocabulary Before Using Digital Storytelling

\begin{tabular}{|c|c|c|c|c|c|}
\hline \multirow{2}{*}{ No. } & \multirow{2}{*}{ Statements } & \multicolumn{4}{|c|}{ Options } \\
\hline & & Yes & $(\%)$ & No & (\%) \\
\hline \multicolumn{6}{|c|}{ Intrinsic Motivation } \\
\hline 1 & I learn vocabulary because I want to master English. & 10 & 45.55 & 12 & 55.45 \\
\hline 2 & $\begin{array}{c}\text { I learn vocabulary because learning vocabulary is } \\
\text { pleasant. }\end{array}$ & 7 & 31.82 & 15 & 68.18 \\
\hline 3 & $\begin{array}{l}\text { I learn vocabulary because I want to know many new } \\
\text { words. }\end{array}$ & 4 & 18.18 & 18 & 81.82 \\
\hline 4 & $\begin{array}{l}\text { I still learn vocabulary although I often have mistakes } \\
\text { and errors. }\end{array}$ & 7 & 31.82 & 15 & 68.18 \\
\hline 5 & I learn vocabulary from my mistakes and errors. & 7 & 31.82 & 15 & 68.18 \\
\hline \multicolumn{6}{|c|}{ Extrinsic Motivation } \\
\hline 6 & $\begin{array}{l}\text { I learn vocabulary because English is a compulsory } \\
\text { subject in my school. }\end{array}$ & 20 & 90.91 & 2 & 9.09 \\
\hline 7 & $\begin{array}{l}\text { I learn vocabulary because I am asked by my teacher } \\
\text { and my parents. }\end{array}$ & 15 & 68.18 & 7 & 31.82 \\
\hline 8 & I learn vocabulary because I want to get a good score. & 19 & 86.36 & 3 & 13.64 \\
\hline 9 & $\begin{array}{l}\text { I learn vocabulary because I do not want to get } \\
\text { punishment from my teacher. }\end{array}$ & 18 & 81.82 & 4 & 18.18 \\
\hline 10 & $\begin{array}{l}\text { I learn vocabulary because I will get an appreciation } \\
\text { from my teacher when I get a good score. }\end{array}$ & 17 & 77.27 & 5 & 22.73 \\
\hline
\end{tabular}

The description of the result of questionnaires:

a. Intrinsic Motivation

In the first statement, $55.45 \%$ students still have a lack of motivation to learn vocabulary, and it affects their English mastery. In the second statement, only 31.82 students feel that vocabulary learning is pleasant, so $68.18 \%$ students do not have great interest in learning. In the third statement, only $18.18 \%$ students want to know many new words, so $81.82 \%$ students still do not have enthusiasm to improve their vocabulary. In the fourth and fifth statements, only $31.82 \%$ students have great motivation in learning vocabulary and most of them do not learn vocabulary from their mistakes and errors.

b. Extrinsic Motivation

In the first statement, 90.91\% students learn vocabulary because English is a compulsory subject in their school. In the second statement, $68.18 \%$ students learn vocabulary because of being asked by their teacher and their parents. In the third statement, $86.36 \%$ students learn vocabulary because of a good 
score. Here, grade still dominates students to learn vocabulary. They learn vocabulary due to external factor, not from the desire to learn vocabulary. In the fourth statement, $81.82 \%$ students learn vocabulary because of avoiding punishment from their teacher. It can be concluded that external factor still dominates students to learn vocabulary. In the fifth statement, $72.73 \%$ students learn vocabulary because of appreciation from their teacher when they get a good score.
From the result of questionnaires, it can be proved that the intrinsic motivation is lower than the extrinsic motivation. Before using digital storytelling, students learn vocabulary because of external factors such as: 1) English is a compulsory subject in their school, 2) they want to get a good score, 3) they are asked by their teacher and their parents, 4) they do not want to get punishment from their teacher, and 5) they will get an appreciation from their teacher when they get a good score.

Table 2. The Recapitulation of Students' Questionnaires

Students' Intrinsic Motivation in Learning Vocabulary After Using Digital Storytelling

\begin{tabular}{|c|c|c|c|c|c|}
\hline \multirow{2}{*}{ No. } & \multirow{2}{*}{ Statements } & \multicolumn{4}{|c|}{ Options } \\
\hline & & Yes & (\%) & No & $(\%)$ \\
\hline \multicolumn{6}{|c|}{ Intrinsic Motivation } \\
\hline 1 & I learn vocabulary because I want to master English. & 22 & 100 & - & - \\
\hline 2 & $\begin{array}{l}\text { I learn vocabulary because learning vocabulary is } \\
\text { pleasant. }\end{array}$ & 19 & 86.36 & 3 & 13.64 \\
\hline 3 & $\begin{array}{l}\text { I learn vocabulary because I want to know many new } \\
\text { words. }\end{array}$ & 16 & 72.73 & 6 & 27.27 \\
\hline 4 & $\begin{array}{l}\text { I still learn vocabulary although I often have mistakes } \\
\text { and errors. }\end{array}$ & 16 & 72.73 & 6 & 27.27 \\
\hline 5 & I learn vocabulary from my mistakes and errors. & 17 & 77.27 & 5 & 22.73 \\
\hline \multicolumn{6}{|c|}{ Extrinsic Motivation } \\
\hline 6 & $\begin{array}{l}\text { I learn vocabulary because English is a compulsory } \\
\text { subject in my school. }\end{array}$ & 22 & 100 & - & - \\
\hline 7 & I learn vocabulary because I am asked by my teacher. & 6 & 27.27 & 16 & 72.73 \\
\hline 8 & I learn vocabulary because I want to get a good score. & 8 & 36.36 & 14 & 63.64 \\
\hline 9 & $\begin{array}{c}\text { I learn vocabulary because I do not want to get } \\
\text { punishment from my teacher. }\end{array}$ & 6 & 27.27 & 16 & 72.73 \\
\hline 10 & $\begin{array}{l}\text { I learn vocabulary because I will get an appreciation } \\
\text { from my teacher when I get a good score. }\end{array}$ & 2 & 9.09 & 20 & 90.91 \\
\hline
\end{tabular}


The description of the result of questionnaires:

There are two parts in this questionnaires; they are, intrinsic motivation and extrinsic motivation. Below is the explanation of each of them.

a. Intrinsic Motivation

In the first statement, all students learn vocabulary to master English. In this statement. It means that all of them have high spirit and high motivation in learning vocabulary. Of course, all of them will yield good effect on students' English mastery. In the second statement, $\quad 86.36 \%$ students learn vocabulary because learning vocabulary is pleasant. It means that digital storytelling can make vocabulary learning exciting. When the learning can make students happy, it improves their intrinsic motivation in learning. In the third statement, $72.73 \%$ students learn vocabulary because they want to know many new words. It means that most of students have a great desire to improve their vocabulary. The high percentage indicates the level of improvement of intrinsic motivation. In digital storytelling, students can find many new words, and those can improve their vocabulary mastery. When students have high intrinsic motivation, they can have better vocabulary mastery. In the fourth statement, $72.73 \%$ students still learn vocabulary although they often have mistakes and errors. It means that most of students have high intrinsic motivation in learning vocabulary because they want to still learn vocabulary although they often have mistakes and errors. Here, after students learn vocabulary with digital storytelling, mistakes and errors still can improve the level of their intrinsic motivation in learning vocabulary. In the fifth statement, $77.27 \%$ students learn vocabulary from their mistakes and errors. Here, mistakes and errors become learning tools for students to learn vocabulary, and those improve their intrinsic motivation in learning vocabulary.

b. Extrinsic Motivation

In the first statement, all students learn vocabulary because English is a compulsory subject in their school. In the second statement, $27.27 \%$ students learn vocabulary because of being asked by their teacher and their parents. The rest of students learn vocabulary because they really want to learn, not because of being asked by their teacher and parents. It means that the intrinsic motivation is higher than he extrinsic motivation. In the third statement, $63.64 \%$ students do 
not learn vocabulary for getting a good score. It means that most of students have high intrinsic motivation in learning vocabulary because they want to master vocabulary, not because they want to get a good score. In the fourth statement, most of students have high intrinsic motivation in learning vocabulary because they want to master vocabulary, not due to avoiding the punishment from their teacher. In the fifth statement, almost all of students have high intrinsic motivation in learning vocabulary because they want to master vocabulary, not due to getting appreciation from their teacher after getting a good score.

From the result of questionnaires, it can be proved that the intrinsic motivation is high. After students learn vocabulary by using digital storytelling, they learn vocabulary due to internal factors such as: 1) they want to master English, 2) learning vocabulary is pleasant, 3) they want to know many new words, 4) they still learn vocabulary although they have errors and mistakes, and 5) they learn vocabulary from their mistakes and errors.

Compared to the result of students' questionnaires before using digital storytelling, there was significance difference on students' motivation in learning vocabulary. After using digital storytelling, students' awareness about the importance of learning vocabulary is improving. It affects students' intrinsic motivation in learning, so they have great enthusiasm in learning vocabulary. They want to know many new words, so that they can apply them inside and outside English classroom interaction. Of course, by having lots of vocabularies, they can improve their language proficiency and their language skills such as: listening, speaking, reading, and writing. Viewed from students' interest on the lesson, digital storytelling gives interesting learning situation because students always feel happy during the lesson and they feel that learning vocabulary is pleasant. Digital storytelling makes them always interested in learning vocabulary although they have errors and mistakes; moreover, they learn vocabularies from their errors and mistakes. Thus, they can master English well, especially for vocabulary.

2. What are the benefits of using digital storytelling to improve students' intrinsic motivation for better vocabulary mastery?

To answer this research question, the researcher 
conducted

one-on-one

interviews to six students who got very high score in adjective test. From the result of the interview, the researcher found that digital storytelling could improve students' intrinsic motivation in learning vocabulary for better vocabulary mastery. They could explore many vocabularies because they could find many adjectives in digital storytelling. They also stated that digital storytelling was an interesting media, and it could enhance their motivation in learning vocabulary. In learning vocabulary through digital storytelling, students could learn vocabulary in an interesting way because it provided pictures, narrations, transitions, music, and voices. Students could also follow the material well because the teacher had set the speed of the digital storytelling. For each sentence containing adjectives, the slides will be played slower to enable students to have a better understanding about the material. It was different when the teacher explained adjective materials with a book or picture only, students felt bored and had no motivation in learning. In addition, after students learned vocabulary using digital storytelling, the intrinsic motivation is higher than the extrinsic motivation. They learned vocabulary because they felt that learning vocabulary was really exciting. Although they had errors and mistakes during learning processes, they still had high spirit in learning. They also believed that learning vocabulary would influence their English skills such as: listening, speaking, reading, and writing. Moreover, they started to learn vocabulary with many ways to improve their vocabulary mastery, so they could improve their language proficiency.

\section{CONCLUSION}

Based on the research, it can be concluded that there was significant improvement after using digital storytelling towards students' intrinsic motivation for learning vocabulary. To investigate the effect of using digital storytelling on students' intrinsic motivation, the researcher conducted close-ended questionnaires. From the result of the questionnaires, before using digital storytelling, the intrinsic motivation is lower than the extrinsic motivation; however, after using digital storytelling, the intrinsic motivation is higher than the extrinsic motivation. From the result of the interview, the researcher found that digital storytelling could improve students' intrinsic motivation in learning vocabulary, so students have better vocabulary mastery. They could explore many 
vocabularies because they could find many new words in the digital storytelling. They also found that digital storytelling is an interesting media, and it can enhance their motivation in learning vocabulary. In learning vocabulary through digital storytelling, students can learn vocabulary in an exciting way because it provides pictures, narrations, transitions, music, and voices. Students can also follow the material well because the teacher had set the speed of the digital storytelling. For each sentence containing adjectives, the slides will be played slower to enable students to have a better understanding about the material. There was also emphasis on adjectives contained in the digital storytelling. The researcher translated every adjective into Bahasa Indonesia to improve students' understanding about adjectives to enable them to apprehend the meaning of adjectives (receptive vocabulary) and to apply the adjectives they know in everyday communication (productive vocabulary). Compared to the learning process before using digital storytelling, when the teacher explained adjective materials with a book or pictures only, students felt bored and had low intrinsic motivation in learning vocabulary; however, after using digital storytelling, students had high intrinsic motivation in learning vocabulary. Of course, by having high intrinsic motivation in learning vocabulary, students could improve their vocabulary mastery, so they have better vocabulary mastery.

\section{REFERENCES}

Al-Amri, H. M. (2019). Fostering Intrinsic Motivation and Willingness to Communicate in English as a Foreign Language Classrooms: The Case of Digital Storytelling. Multi-Knowledge Electronic Comprehensive Journal For Education And Science Publications (MECSJ), 19, 1-17.

Alismail, H. A. (2015). Integrate Digital Storytelling in Education. Journal of Education and Practice, 6(9), 126-130.

Alizadeh, I. (2016). Vocabulary Teaching Techniques: A Review of Common Practices. International Journal of Research in English Education', 1(1), 22-30.

Alqahtani, M. (2015). THE IMPORTANCE OF VOCABULARY IN LANGUAGE LEARNING AND HOW TO BE TAUGHT. International Journal of Teaching and Education, 3(3), 21-34. https://doi.org/10.20472/TE.2 015.3.3.002

Amelia, L. C. H., \& Abidin, M. J. Z. (2018). Young ESL Learners' Perception on the Effects of Using Digital Storytelling Application in English Language Learning. Pertanika J. Soc. Sci. \& Hum, 179-198. 
Bai, Z. (2018). An Analysis of English Vocabulary Learning Strategies. Journal of Language Teaching and Research, 9(3), 853-859.

http://dx.doi.org/10.17507/jltr .0904 .24

Heigham, J., \& Croker, R. A. (2009). Qualitative Research in Applied Linguistics A Practical Introduction (first). PALGRAVE MACMILLAN.

Khorasgani, A. T., \& Khanehgir, M. (2017). TEACHING NEW VOCABULARY TO IRANIAN YOUNG FL LEARNERS: USING TWO METHODS TOTAL PHYSICAL RESPONSE AND KEYWORD METHOD. International Journal of Languages' Education and Teaching, 5(1), 90-100. https://doi.org/10.18298/ijlet. 1729

Long, C., Ming, Z., \& Chen, L. (2013). The Study of Student Motivation on English Learning in Junior Middle School-A Case Study of No.5 Middle School in Gejiu. English Language Teaching, 6(9), 136145.

https://doi.org/10.5539/elt.v6 n9p136

Mahadi, T. S. T., \& Jafari, S. M. (2012). Motivation, Its Types, and Its Impacts in Language Learning. International Journal of Business and Social Science, 3(24), 230-235.

Ng, C. F., \& Ng, P. K. (2015). A Review of Intrinsic and Extrinsic Motivations of ESL Learners. International Journal of
Languages, Literature and Linguistics, 1(2), 98-105. https://doi.org/0.7763/IJLLL.2 015.V1.20

Panagiotidis, P., Krystalli, P., \& Arvanitis, P. (2018). Technology as a Motivational Factor in Foreign Language Learning. European Journal of Education, 1(3), 43-52.

Rehman, A., Bilal, H. A., Sheikh, A., Bibi, N., \& Nawaz, A. (2014). The Role of Motivation in Learning English Language for Pakistani Learners. International Journal of Humanities and Social Science, 4(1), 254-258.

Robin, B. R. (2016). The Power of Digital Storytelling to Support Teaching and Learning. Digital Education Review, 30, 17-29.

Smeda, N., Dakich, E., \& Sharda, N. (2014). The effectiveness of digital storytelling in the classrooms: A comprehensive study. Smart Learning Environments, 1(6), 1-21. https://doi.org/10.1186/s4056 1-014-0006-3

Tiba, C., Condy, J., Chigona, A., \& Tunjera, N. (2013). Digital storytelling as a tool for teaching: Perceptions of preservice teachers. TD The Journal for Transdisciplinary Research in Southern Africa, 10(3), 285-301. 